\title{
Proposal of an Axial Gap Magnetic Gear
}

\author{
Katsuhiro Hirata Senior Member (Osaka University) \\ Masafumi Yamamoto Non-member (Osaka University) \\ Masari Muramatsu Student Member (Osaka University)
}

Keywords: magnetic gear, axial-type, finite element method, transmission torque

Magnetic gears have some benefits such as low noise, low vibration, and they are maintenance-free as opposed to mechanical gears. In view of these advantages, some high-performance magnetic gears have been proposed; however, these gears have a complex structure because they require several magnets. In this paper, we propose a new magnetic harmonic gear with a high reduction ratio comprising only two magnets.

Fig. 1 shows the structure of the magnetic gear. This model has three parts: high speed rotor, low speed rotor, and stator. The high speed rotor comprises two sector rare-earth permanent magnets and a back yoke. The low speed rotor comprises of 20 ferromagnetic pole-pieces and back yoke. The stator comprises 22 ferromagnetic pole-pieces laid between the two rotors. The gear ratio is obtained using the following equation:

$$
G_{r}=\frac{n_{s}-n_{h}}{n_{h}}=\frac{n_{l}}{n_{h}}=10
$$

where $n_{h}, n_{s}$, and $n_{l}$ is the number of poles on the high speed rotor, stator, and low speed rotor, respectively. The resulting gear ratio depends on the number of magnets and on the number of poles of the low speed rotor and stator. The 3D-FEM is employed to study the torque characteristics of this model.

Fig. 2 shows the torque waveforms generated by the low and high speed rotors when only the high speed rotor is allowed to rotate. It is observed that the maximum torque is $7 \mathrm{Nm}$; however, the cogging torque is very large as compared with the maximum torque because of the sector angle of magnets with high speed rotor $\left(\theta_{m}=90^{\circ}\right)$.

In order to reduce the cogging torque, the sector angle of the magnets is changed from $\theta_{m}=90^{\circ}$ to $\theta_{m}=82^{\circ}$. Moreover, the geometry of the ferromagnetic pole-pieces of the stator and low speed rotor is changed from the rectangular form to the sector form to improve the maximum torque.

Fig. 3 shows the comparison of the torque waveforms generated using a sector angle $\theta_{m}=82^{\circ}$. It is observed that the cogging torque decreases by $40 \%$, and the maximum torque increases by $21 \%$ as compared the cogging torque and maximum torque of initial model, respectively.

From the results, it was found that our model generated large transmitted torque and less cogging torque despite its thin compact size. This result shows the possibility of the application of the magnetic gear applying in various industries.

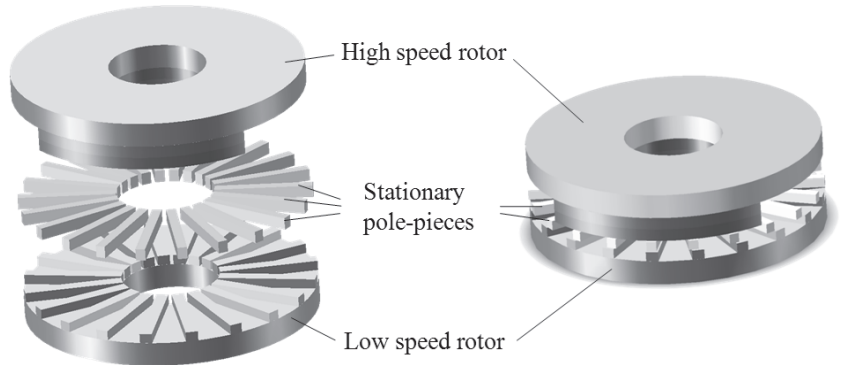

Fig. 1. Structure of axial gap magnetic gear

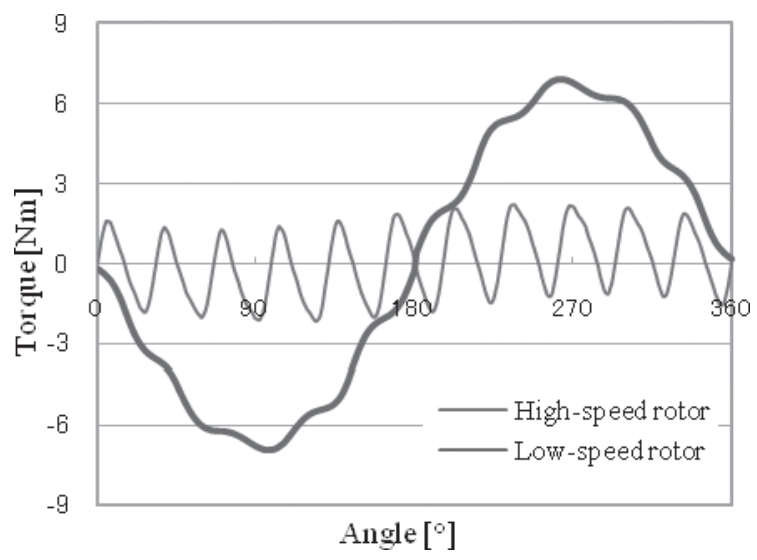

Fig. 2. Torque waveforms of the low and high speed rotors with sector magnetic pole segments (Initial model)

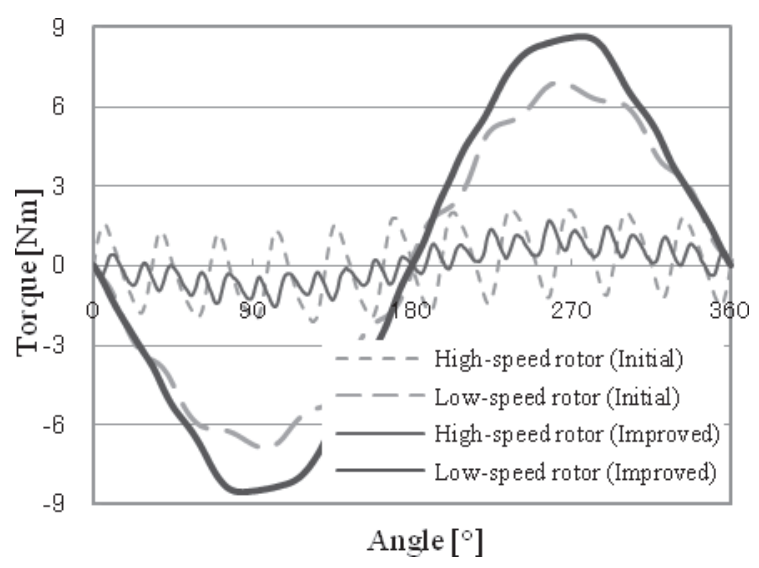

Fig. 3. Comparison of the torque waveforms generated by the initial and improved models 


\title{
アキシャルギャップ形磁気減速機
}

\author{
上級会員 平田 勝弘* 非会員 山本 優文* \\ 学生員 村松 雅理*
}

\section{Proposal of an Axial Gap Magnetic Gear}

\begin{abstract}
Katsuhiro Hirata*, Senior Member, Masafumi Yamamoto*, Non-member, Masari Muramatsu*, Student Member
\end{abstract}
Magnetic gears have some benefits such as low noise, low vibration, and they are maintenance free as opposed to mechanical gears. In the view of these advantages, some high-performance magnetic gears have been proposed; however, these gears have a complex structure because they require several magnets. In this paper, we propose a new magnetic gear with a high reduction ratio comprising only two magnets. From the result of 3D-FE analysis, it was found that our model generated large transmitted torque and less cogging torque despite its thin compact size. This result shows the possibility of the application of the proposed gear in various industries.

キーワード：磁気減速機, アキシャル形, 有限要素法, 伝達トルク

Keywords: magnetic gear, axial-type, finite element method, transmission torque

\section{1. 緒言}

現在減速機は幅広い場面で活用されており，主に高速で 回転する原動機の回転数と駆動力を用途に適するように, 動力源と負荷との間に用いられる。しかし減速機は, 機械 的接点で駆動力を伝達することから, 騒音, 振動, 耐久性 といった様々な課題がある。これらの課題点を解決する磁 気伝達減速機構は, 永久磁石による磁気吸引力・反発力を 用いて非接触で力の伝達を行い, 摩擦や磨耗を起こさずに 動力を伝達できるため, 低騒音, 低振動, メンテナンスフ リーといった優れた特徵を持つ。しかしながら，伝達可能 なトルクが低く，信頼性に欠けていたために，長い間実用 化されることはなかった。

近年, この磁気伝達減速機構が注目を浴びてきている。 その理由として, 高エネルギーを有する希土類磁石が開発 されたことである。更に, 高減速比を実現する様々な新し い構造の磁気伝達減速機構が提案されてきたことが挙げら れる。最近では, K. Atallah, D. Howe らによって Fig. 1 に 示すような高調波磁界を利用した磁気伝達減速機構が提案 された (1) (3)。この減速機構の特徵としては, 磁極片と永久 磁石を組み合わせることで生じる磁束密度分布の高調波成 分をトルク伝達に利用することができる。

\footnotetext{
* 大阪大学大学院工学研究科 知能機能創成工学専攻

于 565-0871 吹田市山田丘 2-1

Dept. of Adaptive Machine Systems, Graduate School of Engineering, Osaka University

2-1, Yamadaoka, Suita 565-0871
}

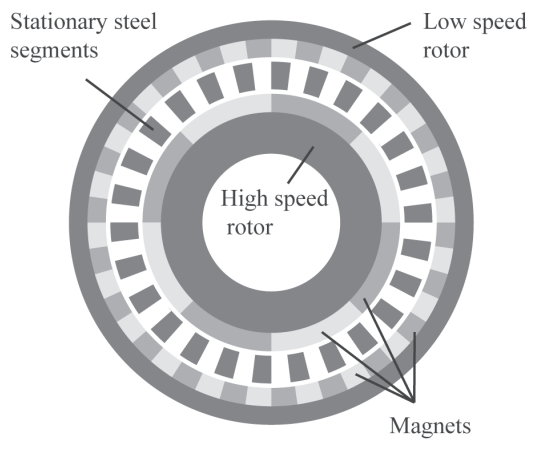

Fig. 1. Harmonic magnetic gear.

この研究によって, 高い伝達トルク密度と高伝達効率を 得ることができることが報告されているが，複数の永久磁 石や多極着磁を必要とするため, 構造が非常に複雑となり, 製作面，コスト面等で課題を抱えている。

本論文では, これらの課題を解決するため, 波動歯車装 置の基本原理を磁気構造によって実現する新しい磁気減速 機構を提案し, その動作原理を説明するとともに, 減速機 性能を確認するために, 三次元有限要素解析によりトルク 伝達特性を明らかにした。

\section{2. アキシャル形磁気伝達減速機構}

$\langle\mathbf{2} \cdot \mathbf{1}\rangle$ 従 来 型我々は, 波動歯車装置の基本原理 を磁気構造によって実現する新しい磁気減速機構の研究を 行ってきた ${ }^{(4)(5)}$ 。Fig. 2 に, その断面図を示す。本減速機構 は, 高速ロータ, 低速ロータ, 両ロータ間に挿入したステー 


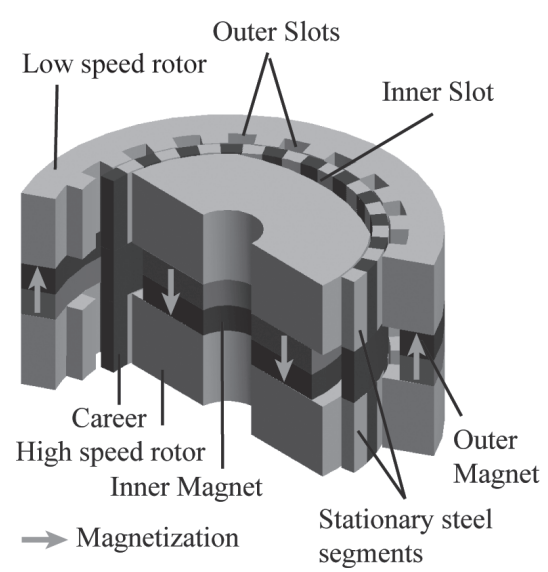

Fig. 2. Radial gap-type magnetic gear.

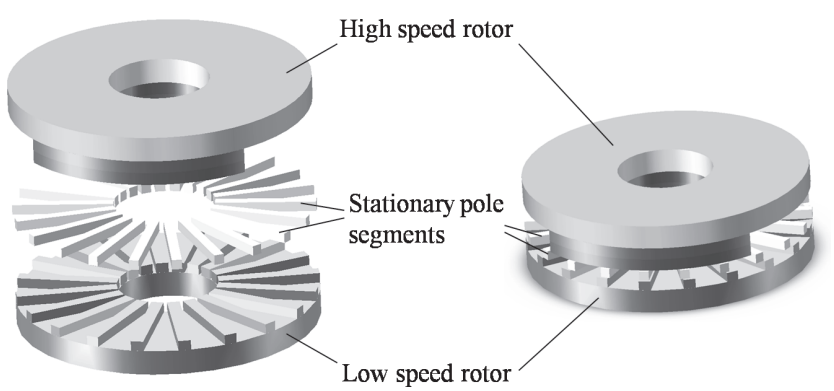

Fig. 3. Axial gap-type magnetic gear.

夕から成る。各ロータにはアキシャル方向に着磁されたリ ング磁石が挿入されており，ステー夕は両ロータの磁極間 のギャップに挿入された磁極片が等間隔 (角度) で配置して いる。磁石埋め込み形の構成としているため，製作面，コ スト面で優れており，比較的簡単な磁気構成で $7 \mathrm{Nm}$ と高 トルク伝達を実現した。

$\langle\mathbf{2} \cdot \mathbf{2}\rangle$ アキシャル形磁気減速機構 次に, このラジ アル形磁気減速機構の磁気回路をアキシャル形とすること で, 薄形で高減速比を得ることができる磁気減速機構を提 案する。本減速機構では，2つのアキシャル方向へ着磁さ れた扇形磁石を有する高速ロー夕と複数の磁極片からなる ステータ及び低速ロータによって非常に高い減速比を実現 できる。Fig. 3 に，本論文で提案するアキシャル形磁気伝 達減速機構を示す。なお，支持機構等は省いている。この 減速機構の磁気回路構成として, 高速ロー夕, 低速ロー夕, 両ロー夕間のギャップに挿入したステータからなる。高速 ロー夕は，回転軸の中央にモー夕軸を通すための軸穴を有 し，ロータコアに，アキシャル方向に着磁された扇形状の 磁石が 2 つ対向するように装着されている。低速ロー夕は, 複数の磁極（スロット）を有し, ステータは, 低速ロータ 及び高速ロータの磁極間のギャップに㨂入された長方形の 磁極片が等間隔 (角度) で配置されている。これら磁極片 は非磁性体で一体化（一体成形）される。磁石は， NdFeB $(\mathrm{Br}=1.4 \mathrm{~T}, \mathrm{Hc}=-1114 \mathrm{kA} / \mathrm{m})$ 希土類磁石を, 各ロー夕 及びステータの磁性体には, 電磁軟鉄（SUY）を使用して いる。

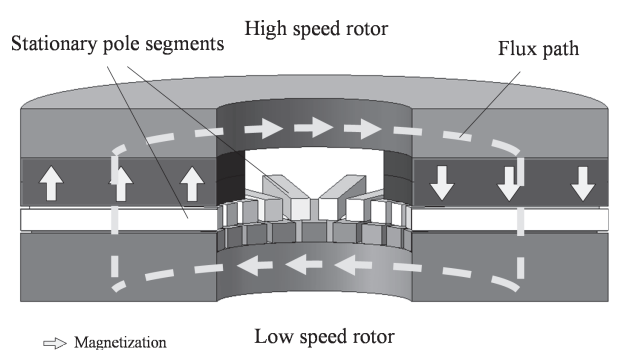

Fig. 4. Cross-section and magnetic circuit of the gear.

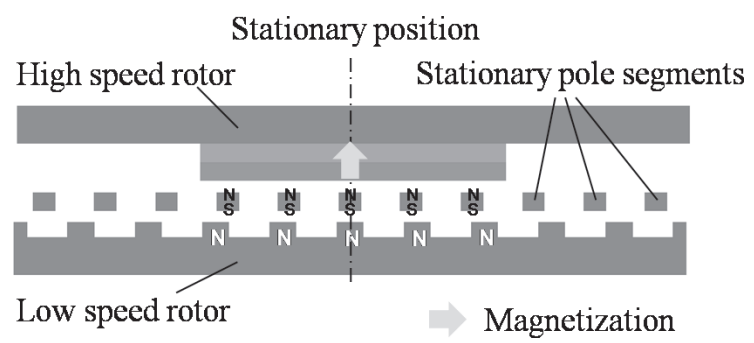

(a) Stationary position

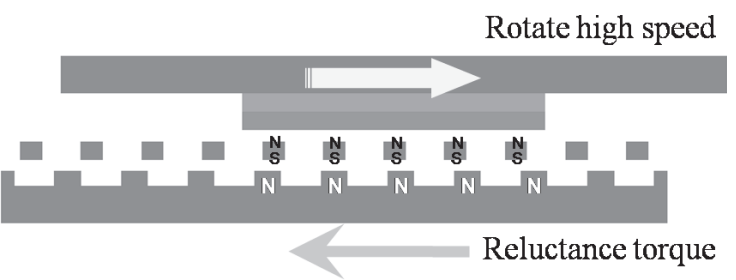

(b) Transmitting torque

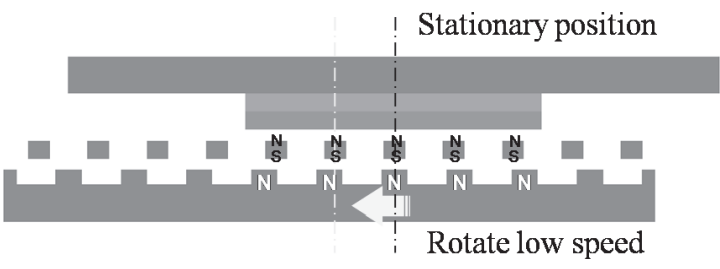

(c) No load

Fig. 5. Principle of axial gap-type magnetic gear rotation.

Fig. 2 のラジアル形減速機構は, ロータとステータ間に半 径方向のギャップを有すのに対し, 本論文で提案する磁気 伝達減速機構は, 軸方向にギャップを有する。これにより, 本アキシャル形減速機構はラジアル形減速機構と比較して ステータの磁極片を一平面上に形成することができ, 図の ように非常に簡易で薄形の構造となる。

〈2.3〉 動作原理 Fig.4に, アキシャル形磁気減速減 速機構の軸方向の断面図を示す。本図において, 矢印は磁 束の流れを示している。アキシャル方向にそれぞれ着磁さ れた磁石からの磁束が, 高速ロータから, ステータ, 低速 ロータを通って高速ロータに戻るように流れる。

Fig. 5 に, 本減速機構の回転動作及びトルク伝達原理を 示す。なお, 困は磁石を中心として $180^{\circ}$ 分を平面上に展開 したものである。(a)に示すように, 無負荷時では高速ロー 夕に装着された磁石により磁束はギャップを通り, ステー 夕磁極片及び低速ロー夕磁極片がそれぞれ磁化される。各 磁極片に流れる磁束は中心に対して平衡しておりトルクが 
発生せずに安定となる。(b) では, 高速ロータが回転（図中 右方向）することで, 磁束の回転方向成分が増加し, 低速 ロータに高速ロータとは反対方向（図中左方向）のリラク タンストルクが発生し伝達トルクが増加する。無負荷時で は，発生したリラクタンストルクにより (c) のように低速 ロータは回転高速ロータとは反対方向に回転する。このと き高速ロー夕は, ステー夕磁極片の 1 ピッチ分 $\left(360 / 22^{\circ}\right)$ 回転したのに対し, 低速ロータは 360/20-360/22 回転し ており, これは本減速機の減速比分の 1 に相当し, 減速し ていることがわかる。すなわち, 高速側が回転し磁気減速 機にエネルギーが加えられ，蓄えられたエネルギーが低速 側に伝わることで, 高速側に加えた 10 倍のトルクが低速 側に発生し, 通常の減速機同様の効果が得られていること がわかる。

$\langle\mathbf{2} \cdot \mathbf{4}\rangle$ 減 速 比減速比は, 本減速機構の動作原理が 波動歯車装置の基本原理に基づくため, 高速ロー夕及び低 速ロー夕の磁極数で決定される。本モデルでは, 高速ロー

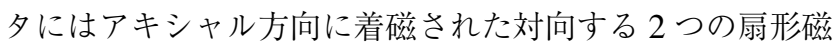
石で構成している。

減速比 $G r$ は次式で表される。

$$
G_{r}=\frac{n_{l}}{n_{h}}
$$

ここで, $n_{l}, n_{h}$ は低速ロータ及び高速ロー夕の磁極数（又 ロット数) である。このときに使用するステー夕磁極数 $n_{s}$ は次式で表される。

$$
n_{s}=n_{l} \pm n_{h} \quad\left(n_{s}>n_{h}\right)
$$

なお，式中の符号が正の場合は高速ロー夕と低速ロー夕 は反対方向に，負の場合は同方向に回転する。

$n_{l}, n_{h}$ は自由に設定することができるため, 従来の減速 機と比較して, 高い減速比を得ることができるだけでなく, 構造が非常に簡単となり, 製作面, コスト面の課題を解決 できる。

\section{3 次元有限要素法による伝達トルク解析}

提案する減速機構の伝達許容トルクを求めるために, 三 次元有限要素法を用いて磁場解析を行った。解析では，四 面体辺要素を用いている。また，トルクの計算にはマクス ウェルの応力法を用いている。解析モデルの寸法及び解析 条件を Table 1 に示す。Fig. 6 に空気領域を除く有限要素法 モデルを示す。な㧍，電磁軟鉄（SUY）の非線形性を考慮 している。Fig.7 にその磁気特性を示す。

要素数 692,486 , 辺数 814,563 , 節点数 121,641 である。 Intel Core2Duo プロセッサ $2.93 \mathrm{GHz}$ 搭載の PC を用いて 非線形解析を行った結果, 本モデルの解析時間は約 2 時間 となった。

中心からの半径 $r=40 \mathrm{~mm}$ に位置する低速ロー夕とス テータ間のエアギャップの, 安定位置（高速ロー夕回転角 $\left.\theta=0^{\circ}\right)$ 及びトルク伝達時（高速ロー夕回転角 $\theta=50^{\circ}$ ）の 磁束密度分布をそれぞれ Fig. 8(a) 及び (b) に示す。いずれ
Table 1. Dimension of analyzed model.

\begin{tabular}{|l|l|}
\hline Number of poles on high speed rotor & 2 \\
\hline Number of poles on Low speed rotor & 20 \\
\hline Number of stationary pole segments & 22 \\
\hline Gear ratio & 10 \\
\hline Height of total magnetic gear & $39.5 \mathrm{~mm}$ \\
\hline Air gap length & $0.5 \mathrm{~mm}$ \\
\hline Back yoke size $\left(r_{o}, r_{i}, h\right)$ & $60,20,10 \mathrm{~mm}$ \\
\hline A piece of the stator pole segment $(d, w, h)$ & $40,4,4.5 \mathrm{~mm}$ \\
\hline A piece of low speed pole segment $(d, w, h)$ & $40,5,4 \mathrm{~mm}$ \\
\hline Radius of the high speed rotor shaft & $20 \mathrm{~mm}$ \\
\hline Magnet size $\left(r_{o}, r_{i}, h\right)$ & $60,20,10 \mathrm{~mm}$ \\
\hline Sector angle of magnet $\left(\theta_{m}\right)$ & $90^{\circ}$ \\
\hline
\end{tabular}

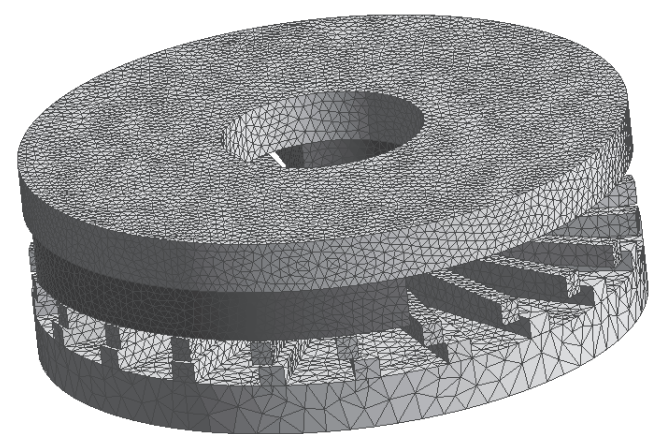

Fig. 6. FEM model.

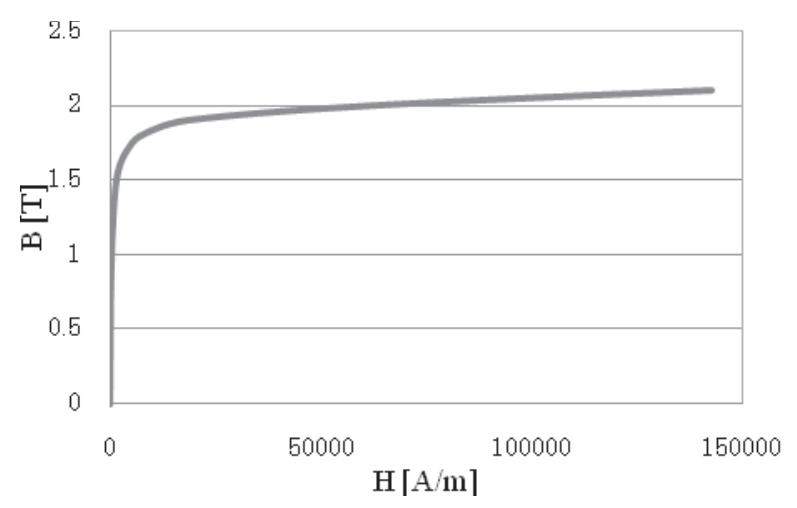

Fig. 7. Magnetization characteristic of SUY.

の場合においても，高速ロータに装着された磁石による磁 束がステー夕磁極片により低速ロー夕とステータ間のエア ギャップに空間高調波を形成していることが確認できる。 安定位置と比較してトルク伝達時では, 約 $0.3 \mathrm{~T}$ 磁束密度 が高くなっている。これは, ステー夕と低速ロー夕の各磁 極片の対向する面積が安定位置の時最大で, 最大卜ルク伝 達時 $\left(\theta=50^{\circ}\right)$ で最も小さくなるためである。この時, 固 定子磁極片では部分的に磁気飽和をおこしている。

低速ロー夕を固定したまま安定位置 $\left(\theta=0^{\circ}\right)$ から高速 ロータを回転させた時の, 低速ロー夕の伝達トルク, 高速 ロータのコギングトルク波形の解析結果を Fig. 9 に示す。 高速ロー夕の回転角が $50^{\circ}$ の時に低速ロー夕側で得られる トルクが最大で, 約 $7 \mathrm{Nm}$ のトルクを伝達できることが示 された。

また, 高速ロータで作用しているコギングトルクが約 $2 \mathrm{Nm}$ 程度発生しており，低速ロータのトルク波形もかなり歪ん でいることが分かる。これは振動・騒音の原因となるため 


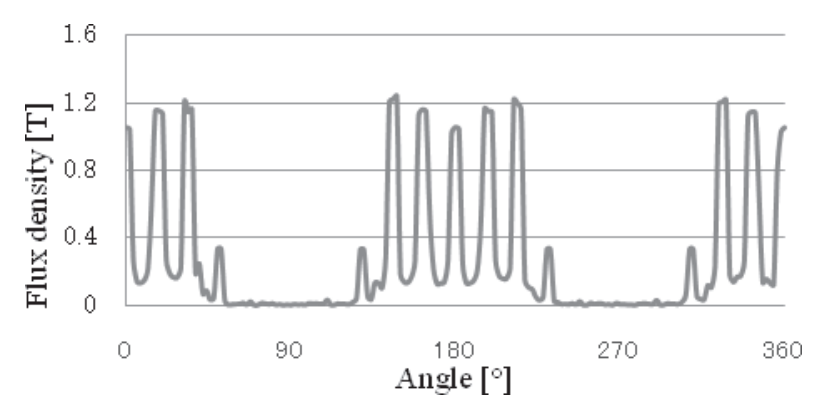

(a) $\theta=0^{\circ}$

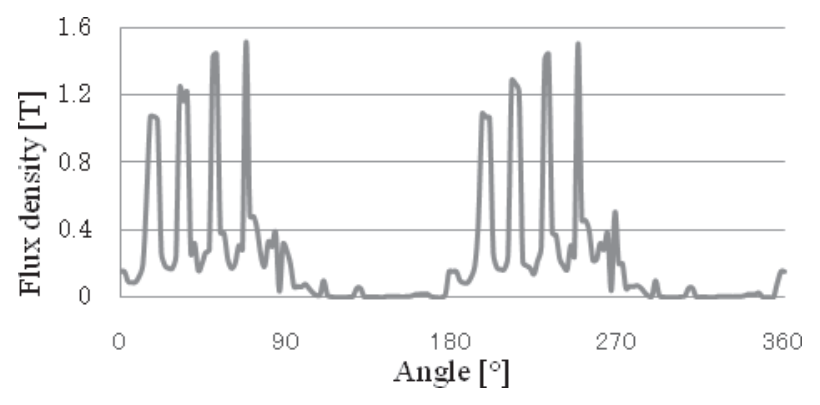

(b) $\theta=50^{\circ}$

Fig. 8. Flux density in the air gap between low speed rotor and stator.

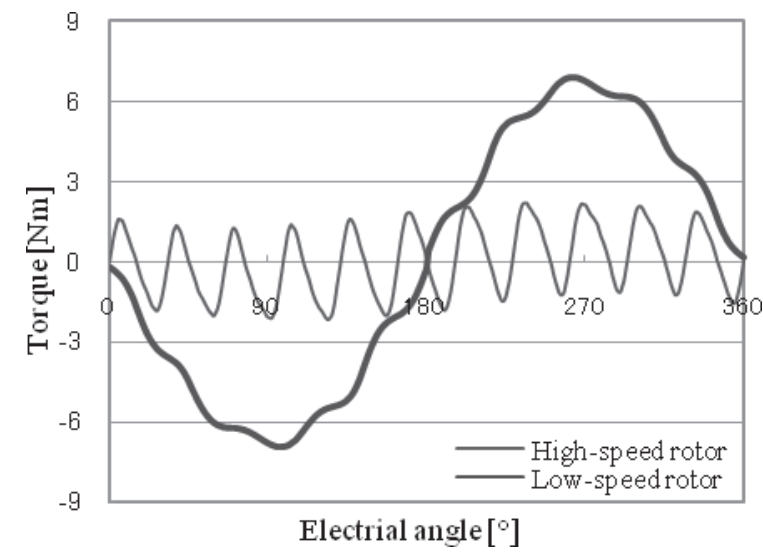

Fig. 9. Torque waveforms on low- and high-speed rotors (Magnet sector angle $\theta_{m}=90^{\circ}$ ).

解消する必要がある。

\section{4. 伝達トルク特性の改善}

〈4・1〉 コギングトルクの低減＼cjkstart前述にて，高速ロー夕 のコギングトルクが大きく, 低速ロータもトルク波形は歪 んでいることが分かった。そこで，高速ロータのコギング トルクの半周期分を機械角とし位相角度を操作することで コギングトルクを低減することを試みる。2つの磁石の位 相角度を $180^{\circ}$ からコギングトルクの半周期分 $(360 / 22 / 2=$ 約 $\left.8^{\circ}\right)$ ずらすことも可能だが, 高速ロー夕の回転平衡が悪 くなるため, 本検討では，扇形磁石の中心角を $90^{\circ}$ からそ れらを除いた $82^{\circ}$ に変更することで，コギングトルクの低 減を試みた。三次元有限要素法により扇形磁石の中心角を $82^{\circ}$ としたモデルでの高速ロータのコギングトルク及び低

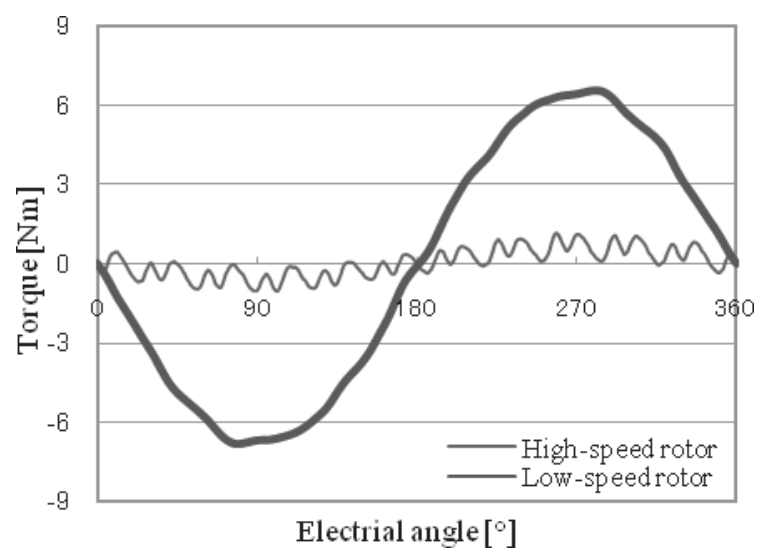

Fig. 10. Torque waveforms on low- and high-speed rotors (Magnet sector angle $\theta_{m}=82^{\circ}$ ).

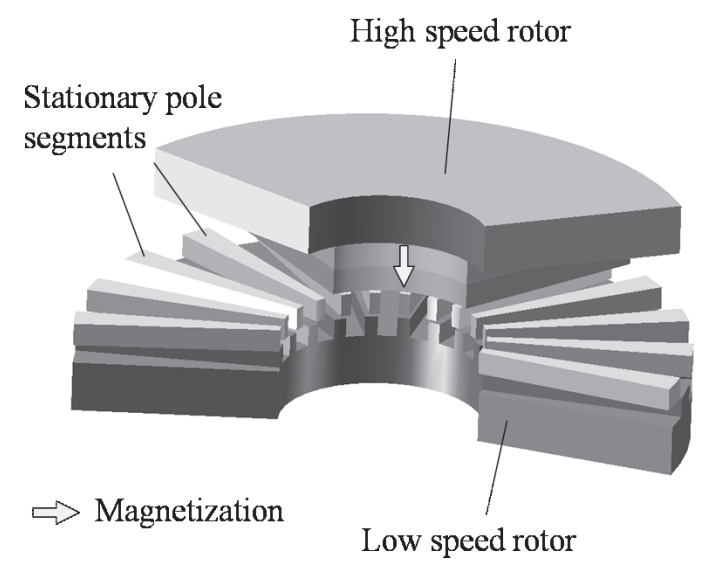

Fig. 11. Sector magnetic pole model.

速ロータの伝達トルク波形を求めた結果を Fig. 10 に示す。 Fig. 9 及び Fig. 10 より, 扇形磁石の中心角を $82^{\circ}$ としたモ デルでは，高速ロータ側のトルク波形が磁石の中心角 $90^{\circ}$ と比較して, 約半分の大きさに抑制できることが確認でき る。また，低速ロー夕の最大伝達卜ルクはほぼ同じで，卜 ルク波形の歪は抑えられている。

〈4・2 磁極片形状による伝達トルクの改善 ステー 夕及び低速ロー夕の磁極片形状は，トルク伝達特性に大き く影響するため，その形状及び寸法を最適化する必要があ る。本検討では，ステータ及び低速ロー夕の磁極片形状を 長方形から，扇形へ変更したアキシャル形磁気伝達減速機 構を Fig. 11 に示す。扇形磁極片を持つ磁気伝達減速機構の 優位性を確認するために，長方形磁極片モデルと同様に三 次元有限要素法を用いて伝達卜ルクを求め, 両者を比較す る。解析モデルの寸法及び条件を Table 2 に示す。

両モデルに抒いて，ステータ及び低速ロータ以外の寸法 は長方形磁極片モデルと同じ条件としている。ここで，低 速ロー夕を固定したまま安定位置から高速ロー夕を回転さ せた時の低速ロータの伝達トルクと, 高速ロータのコギン グトルク波形の解析結果を Fig. 12 に示す。高速ロー夕の回 転角が電気角 $100^{\circ}$ の時に低速ロー夕側で得られるトルク 
Table 2. Dimension of analyzed model (with sector ferromagnetic pole segments).

\begin{tabular}{|l|l|}
\hline Number of poles on high speed rotor & 2 \\
\hline Number of poles on Low speed rotor & 20 \\
\hline Number of stationary pole segments & 22 \\
\hline Gear ratio & 10 \\
\hline Height of total magnetic gear & $39.5 \mathrm{~mm}$ \\
\hline Air gap length & $0.5 \mathrm{~mm}$ \\
\hline Back yoke size $\left(r_{o}, r_{i}, h\right)$ & $60,20,10 \mathrm{~mm}$ \\
\hline A piece of the stator pole segment $\left(r_{o}, r_{i}, h\right)$ & $60,20,4.5 \mathrm{~mm}$ \\
\hline A piece of the stator pole segment $\left(\theta_{S}\right)$ & $6^{\circ}$ \\
\hline A piece of low speed pole segment $\left(r_{o}, r_{i}, h\right)$ & $60,20,4 \mathrm{~mm}$ \\
\hline A piece of low speed pole segment $\left(\theta_{L}\right)$ & $7.2^{\circ}$ \\
\hline Radius of the high speed rotor shaft & $20 \mathrm{~mm}$ \\
\hline Magnet size $\left(r_{o}, r_{i}, h\right)$ & $60,20,10 \mathrm{~mm}$ \\
\hline Sector angle of magnet $\left(\theta_{m}\right)$ & $82^{\circ}$ \\
\hline
\end{tabular}

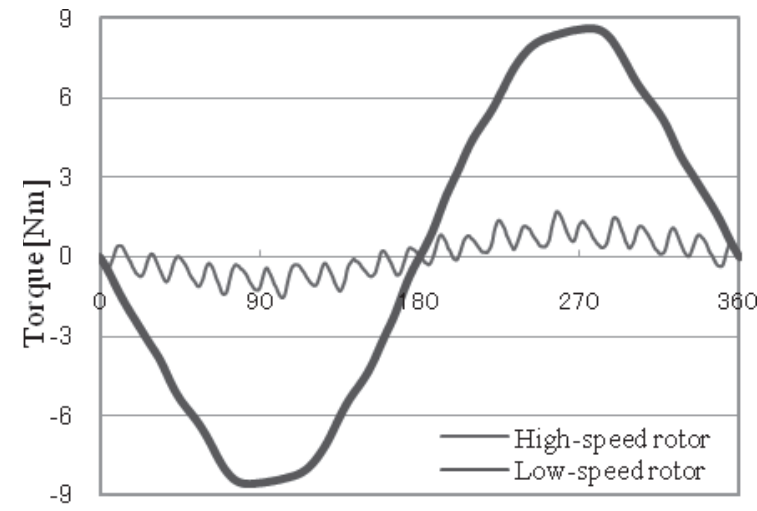

Electrical angle $\left[{ }^{\circ}\right]$

Fig. 12. Torque waveforms on low- and high-speed rotors (with sector magnetic pole segments).

の最大值約 $8.5 \mathrm{Nm}$ を実現した。長方形磁極片モデルと比 較して, 約 $1.5 \mathrm{Nm}$ 伝達トルクが向上した。これは磁極片 を扇形形状にすることで，高速ロー夕における磁石のエッ ジとステータの磁極片のエッジ部分, 及びステータの磁極 片のエッジと低速ロー夕の磁極片のエッジ部分がそれぞれ 平行に対向することで，回転方向の磁束成分が増加し，伝 達許容トルクが向上したと考えられる。

$\langle\mathbf{4} \cdot \mathbf{3}\rangle$ 同期回転時のトルク特性 コギングトルクは (1) 式に示すギア比から，2 つのロー夕を同期回転させる ことで高速ロー夕側に発生するトルクから伝達トルクを求 めることができる。無負荷時での伝達卜ルク波形を Fig. 13 に示す。また，予め低速ロー夕に対する高速ロー夕の位相 を電気角 $60^{\circ}$ 分回転した負荷伝達時での伝達卜ルク波形を Fig. 13 に示す。なお，この時低速ロー夕側には Fig. 12 よ り約 $7 \mathrm{Nm}$ の伝達トルクが発生する。

無負荷時及び負荷伝達時共に, 高速側にはステータの磁 極片数と同周期の正弦波状のコギングトルクが確認でき, その振幅は約 $1 \mathrm{Nm}$ であることがわかる。低速側にも同周 期のコギングトルクが発生しているものの，高速側に比べ てその振幅は非常に小さい。Fig. 14 には, 低速側のトルク の平均值を，ギア比で割った值も加えて示す。これにより， 低速側には高速側のトルクの平均值の約 10 倍のトルクが 発生していることがわかる。

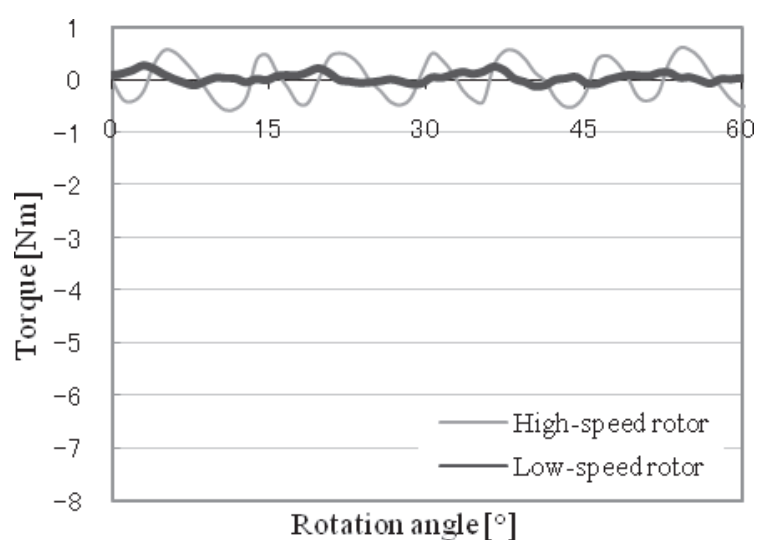

Fig. 13. Cogging torque waveforms (no load).

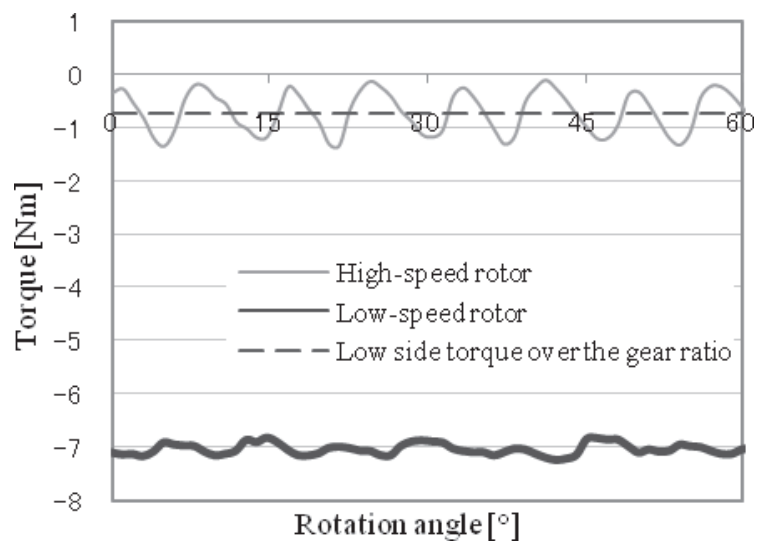

Fig. 14. Cogging torque waveforms (High speed rotor angle $\theta=30^{\circ}$ ).

\section{5. まとめ}

本研究では, 波動減速装置の基本原理を磁気構造によっ て実現するアキシャル形磁気減速機構を提案し，その動作 原理を説明するともに，三次元有限要素法を用いてその伝 達トルク特性及びコギングトルク特性を求め, 本減速機の 有効性を明らかにした。更に, 高速ロータのコギングトル クを低減するための扇形磁石角度の検討，伝達トルク向上 のためのステータ及び低速ロー夕の磁極片形状の検討を行 い，その効果を証明した。

今後は, 試作機を製作し, 実機での伝達許容トルクやコ ギングトルクならびに伝達効率の評価を行う予定である。

(平成 21 年 11 月 2 日受付，平成 22 年 1 月 22 日再受付)

\section{文献}

(1) K. Atallah and D. Howe: "A novel high-performance magnetic gear", IEEE Trans. Magn., Vol.37, p.2844 (2001)

(2) K. Atallah, J. Wang, and D. Howe: "A high-performance linear magnetic gear", J. Appl. Phys., Vol.97, p.10N516 (2005)

(3) S. Mezani, K. Atallah, and D. Howe: "high-performance axial-field magnetic gear", J. Appl. Phys., Vol.99, p.08R303 (2006)

(4) 山本優文・平田勝弘：「HB 型磁気伝達減速機構に関する研究」, 第 20 回「電磁力関連のダイナミクス」シンポジウム, pp.77-80 (2008)

（5）山本優文・平田勝弘・村松雅理：「新しい磁気伝達減速機構に関する 研究」,第 17 回 MAGDA コンファレンス,pp.69-74 (2008) 
平田勝 弘 (上級会員) 1958 年 4 月 10 日生。1 982 年 3 月, 大阪大学機械工学科卒業。同年 4 月松下電工 (株), 技術研究所勤務。2005 年大阪大学大学院工学研究 科知能・機能創成工学専攻・助教授を経て, 2007 年同大教授, 現在に至る。主として, 電磁アクチュ エータ, センサデバイス, 有限要素法を用いた電 磁界解析に関する研究に従事。工学博士。2003 年 文部科学大臣賞 (研究功績者) 受賞。2004 年才ー 厶技術賞受賞。2007 年電気学会電気学術振興賞 (進歩賞) 受賞。IEEE 会員他。

山 本 優 文 (非会員) 1983 年 11 月 26 日生。 2006 年 3 月, 大阪大学工学部応用理工学科卒業。2009 年大阪 大学大学院工学研究科修士課程修了。同年 4 月パ ナソニック (株) モータ社勤務, 現在に至る。主 として回転機の研究に従事。
村 松 雅 理 (学生員) 1985 年 11 月 11 日生。 2008 年 3 月,

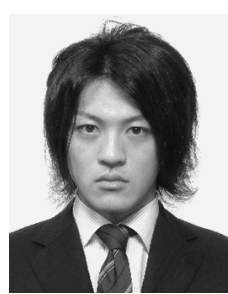
金沢大学機能機械工学科卒業。同年 4 月大阪大学 大学院工学研究科入学, 現在に至る。主として回 転機の研究に従事。

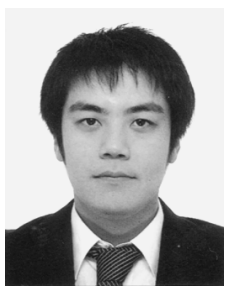

